\title{
Earnings Management in the Aftermath of the Zero-Earnings Discontinuity \\ Disappearance
}

\begin{abstract}
Purpose: The purpose of this paper is to investigate earnings management by firms reporting a small profit or a small loss after the recent evidence that the discontinuity around zero earnings has disappeared.
\end{abstract}

Design/methodology/approach: Using a large sample of US firms for the period 2002-2011, regression analysis and earnings distribution approach are employed to examine the earnings management of small profit and small loss firms in terms of both accruals management and real activities manipulation.

Findings: The results suggest that both small profit and small loss firms are engaged in upward manipulation of accruals and real activities. This implies that failure to document a difference between firms to the right and left of zero by prior studies is not due to small profit firms not managing earnings, but rather this is more attributable to loss firms engaging in upward manipulation. Furthermore, it is indicated that the discontinuity around the distribution of earnings change has also recently disappeared as firms reporting a small earnings decrease demonstrate similar earnings management behavior to those reporting a small earnings increase.

Research limitations/implications: This study is subject to the measurement error which is a common limitation in the earnings management literature.

Practical implications: The results suggest that the users should be aware that, in addition to firms that meet benchmarks by a slight margin, firms narrowly missing benchmarks are also involved in earnings management. 
Originality/value: This study shows that the disappearance of the discontinuity around zero earnings and zero change in earnings should not be interpreted as a sign of no earnings management. It also explains how earnings management could have contributed to the disappearance of the discontinuities in earnings distribution.

Keywords: financial reporting, earnings management, accruals management, real activities manipulation, earnings distribution, earnings discontinuity

Jel classification: M41

\section{Introduction}

Detection of earnings management has long been the subject of heated debate in the accounting literature. In order to uncover earnings manipulation, a common methodology is to associate it with a motivation for earnings management. Earnings management induced by management compensation packages (e.g. Healy, 1985; Skinner, 1993; Baker et al., 2003; Cheng and Warfield, 2005), debt contracts (e.g. Defond and Jiambalvo, 1994; Sweeny, 1994; Dichev and Skinner, 2002; Gupta et al., 2008), targets set by industries (e.g. Beaty et al., 1995; Petroni, 1992), earnings benchmarks (e.g. Burgstahler and Dichev, 1997; Burgstahler and Eames, 2006;

Daske et al., 2006; Gunny, 2010; Das et al., 2009), and cost of capital (e.g. Dechow et al., 1996; Strobl, 2013; Kim and Sohn, 2013) is established in the literature. For decades, the attempts to document earnings management had substantially focused on accruals and discretionary accruals, but a study by Burgstahler and Dichev (1997) embarked on a different route. Instead of calculating discretionary accruals to observe earnings management, they employed natural earnings benchmarks such as avoiding reporting of losses and earnings decreases in order to uncover earnings manipulation. Through this approach, manipulation of earnings is inferred from the pattern of earnings distribution. To this end, the frequency of earnings level or earnings change scaled by a size variable such as total assets or market value is plotted and 
observations are grouped into intervals according to their level of scaled net income. Any distributional irregularity is considered as evidence of earnings management. The only assumption here is that "under the null hypothesis of no earnings management, the crosssectional distribution of earnings changes and earnings levels are relatively smooth" (Burgstahler \& Dichev, 1997, p. 102). Simply stated, it is generally expected that in the absence of earnings management the distribution of earnings would be symmetric. Therefore, if earnings are manipulated to reach an earnings target, it is expected that there will be "too few" frequency of earnings sitting just below the target and "too many" at or above it (Degeorge et al., 1999).

Comparing discretionary accruals of small profit and small loss firms, Dechow et al. (2003) report that the discontinuity in the earnings distribution cannot be associated with accruals management. Hansen (2010) points out that the reason behind earnings management not differing between small loss firms and small profit firms could be that loss avoidance is not the only motivation for earnings management and that incentives other than reporting positive earnings, such as to meet/beat analysts' forecasts or to continue reporting earnings growth, could also encourage earnings management. He provides evidence that firms that missed a lossavoidance benchmark apply accruals management to meet other earnings targets. Koh et al. (2008) examine earnings management to meet or beat market expectations and suggest that after Enron and the passing of the Sarbanes-Oxley Act, the market has become more suspicious of firms meeting/beating earnings benchmarks. The authors show that beating an EPS benchmark by a small margin has also declined in the post-Enron era.

Evidence of a change in earnings management behaviour after the passing of the Act is abundant in the literature (e.g. Cohen et al., 2008; Lobo \& Zhou, 2010) which highlights the monitoring role of corporate governance mechanisms on financial reporting (e.g. Dechow et 
al., 1996; Garcia-Meca \& Sanchez-Ballesta, 2009; Leventis \& Dimitropoulos, 2012; Neifar et al., 2016). A recent study by Gilliam et al. (2015) may be a turning point in studies that use the earnings distribution approach. They reveal that the discontinuity around zero in earnings distribution has faded after the accounting controversy at the turn of the twentieth century. They examine competing hypotheses including the effect of scaling (e.g. Durtschi \& Easton 2005, 2009), sample selection (e.g. Durtschi \& Easton 2005 and 2009; Burgstahler \& Chuk, 2015) and effects of income taxes and special items (Beaver et al., 2007) suggesting that these factors can explain neither the discontinuity nor its fade. However, they do not directly examine earnings management around zero earnings after the disappearance of the discontinuity. Moreover, while they document the disappearance of the discontinuity and indicate that nonearnings management factors cannot explain this phenomenon, they do not provide evidence how earnings management could explain it. The present study fills this gap by providing evidence on earnings management around zero earnings in terms of both accruals management and real activities manipulation. We explain how the recent decline in benchmark-beating earnings management could have contributed to the disappearance of the discontinuity. Looking into both types of manipulation is particularly significant since in order to fully understand earnings management behaviour one should investigate both means of manipulation (Ewert \& Wagenhofer, 2005) and there has been a shift from accruals management to real activities manipulation in the aftermath of high-profile accounting scandals at the turn of the century (Cohen et al., 2008). Moreover, this study provides fresh evidence on the discontinuity in the distribution of earnings changes to investigate the existence or otherwise of the discontinuity reported by Burgstahler and Dichev (1997).

Using a large sample of US firms for the period 2002-2011, the present study examines earnings management around zero earnings and zero change in earnings. In doing so, scaled earnings are plotted and observations just above and below zero are selected and compared 
with the rest of the sample in terms of various measures of earnings management. Providing corroborative evidence that the discontinuity around zero has recently vanished, we find that firms reporting a small loss and those reporting a small profit are similar in terms of earnings management behaviour as both groups are generally engaged in upward manipulation. The evidence on change in earnings is also consistent with the fade of the discontinuity and similar earnings management behaviour is observed for firms located to the right and left of zero change.

The present study makes several contributions to the earnings management literature. Firstly, while Dechow et al. (2003) indicate that small profit firms do not differ from small loss firms in terms of abnormal discretionary accruals, our findings suggest that the two groups are also similarly engaged in real activities manipulation. We argue that the lack of difference between the two groups might not be due to a lack of earnings management by small profit firms. Instead, this might be attributable to similar behaviour by small loss firms. This is not in line with the notion that small loss firms are less likely to be engaged in earnings management because they would need a slight effort to shift from reporting a small loss to reporting a small profit (Burgstahler \& Dichev, 1997; Kerstein \& Rai, 2007). Roychowdhury (2006) reports that small profit firms are engaged in income-increasing manipulation of real activities. Considering the evidence on a relatively recent change in earnings management behaviour (Cohen et al., 2008) and the more recent disappearance of the kink in the earnings distribution (Gilliam et al., 2015), this paper examines earnings management in the post-Enron era by looking into both accruals management and real activities manipulation. The results indicate that small loss firms show almost the same level of upward real activities manipulation as small profit firms. This similarity could be because small loss firms are also engaged in upward manipulation rather than being due to small profit firms not managing their earnings. This suggest that while the recent intensified scrutiny over firms that just beat benchmarks have 
reduced beating benchmarks by a small margin, at the same time it has created a quiet room for some other manipulators to avoid the attention of outsiders by stopping just behind benchmarks and marginally missing them. Secondly, this paper expands the findings of Gilliam et al. (2015) regarding the disappearance of zero-earnings discontinuity to indicate that the discontinuity in the distribution of earnings change which was initially documented by Burgstahler and Dichev (1997) has also recently disappeared. The results reveal that firms with a small earnings decrease are engaged in similar upward manipulation as firms with a small earnings increase. Thirdly, given concentrating on one tiny interval limits the power of tests (Roychowdhury, 2006) and the immediate right of zero has long been considered as the interval most likely to contain earnings management, our results suggest that firms located across a wider area around zero earnings, both to the right and left of zero, are engaged in earnings management. This could potentially increase the power of tests in future studies taking the earnings distribution approach which offers a methodological contribution to the earnings management literature. Fourthly, consistent with the reported recent shift from accruals management to real activities manipulation (Cohen et al., 2008), we provide evidence that firms around zero earnings exhibit a remarkably greater level of real activities manipulation compared to accruals management. A similar inference can be made regarding firms around zero change in earnings.

The rest of this paper is structured as follows. Section 2 surveys prior studies and develops research hypotheses. Section 3 explains sample and research design. The results are presented in Section 4 and, finally, Section 5 provides concluding remarks.

\section{Background and Hypothesis Development}

As Holthausen (1990) points out, opportunistic behaviour, information signalling and efficiency contracting perspectives are capable of explaining earnings management. However, 
self-centred and opportunistic behaviour of management assumed by agency theory is the standard approach used by accounting scholars to explain earnings management (Walker, 2013). To assess the financial performance of firms, investors and other market participants focus on benchmarks rather than absolute values. This tendency can be explained by prospect theory. In contrast to utility theory which assumes that rational decision makers weight the utilities of outcomes by their probabilities, according to prospect theory proposed by Kahneman and Tversky (1979), they actually view outcomes as gains or losses not as the absolute value of wealth. They argue that in order to define gains or losses a reference point is required which could be earnings benchmarks such as zero earnings or expected earnings. Since outsiders focus on achieving earnings benchmarks to assess the financial success of firms, beating benchmarks is important for managers. Opportunist managers may avoid missing earnings benchmarks by means of earnings management. Thus, in order to detect earnings manipulation, studies tend to concentrate on firms that just meet/beat earnings benchmarks to see whether they are involved in manipulation.

If earnings are managed for the purpose of reaching a benchmark then there must be an unusually high number of cases that just meet the benchmark and an unusually low number of cases just missing it, causing a so-called "kink" in the earnings distribution. This anomaly, or kink, in the distribution of earnings is well documented in the literature. Looking into avoiding a loss as a common earnings benchmark, Hayn (1995) was one of the first to notice a discontinuity in earnings distribution around zero. Firms that incurred a small loss could report a small profit through a slight manipulation of their earnings. Although the difference between a small loss and a small profit could be insignificant, due to the so-called 'cognitive reference point', a small profit is perceived as abnormally larger compared to a small loss (Van Caneghem, 2002). Loss avoidance earnings management should be evident where there are an abnormally large number of firms that have just surpassed zero earnings along with an 
abnormally small number of firms reporting a loss, giving rise to a discontinuity in the distribution of earnings. Therefore, the immediate right of zero has been deemed the interval most likely in which to find firms engaged in earnings management. To observe earnings management from earnings distribution, one first needs to understand the shape of the distribution without earnings management. Hayn (1995) defines the expected frequency of earnings as a normal distribution at $1 \%$ significance level using a binominal test. She plots earnings and notices a point of discontinuity around zero with a concentration of observations at the immediate right of zero and an abnormally low number of observations of small losses. She interprets the kink as being indicative of firms that are about to experience a loss crossing "the red line" by engaging in earnings manipulation.

Burgstahler and Dichev (1997) examine earnings management applied to avoid earnings decreases and reporting a loss. They operationalize distribution smoothness as where the expected frequency of observations in each interval is the average of the number of observations in its two neighbouring intervals. They observe an abnormal pattern in the distribution of earnings change and of earnings level and suggest two explanations for their findings. The first of these is avoiding losses and earnings decreases to reduce transaction costs with stakeholders, and the second suggested explanation is a natural reluctance toward absolute and relative losses. Beaver et al. (2003) plot the distribution of earnings scaled by total assets with interval widths of 0.006. Similar to Burgstahler and Dichev (1997), the expected frequency of an interval is considered as the average of the two neighbouring intervals. They also find a discontinuity in the earnings distribution around zero. In a similar vein, Degeorge et al. (1999) indicate how thresholds including loss avoidance, prior period earnings and analysts' forecasts induce certain patterns in earnings distribution. Burgstahler and Eames (2006) provide evidence that firms avoid missing analysts' forecasts by means of both accruals management and real activities manipulation. Using quarterly data, Jacob and Jorgensen (2007) 
also observe discontinuities around zero and prior year earnings. A very recent study by Halaoua et al. (2017) investigates British and French firms in terms of earnings management around zero and earnings change and finds evidence of earnings management by both groups, although they find that the frequency of, and the motivations for, benchmark meeting/beating are different across the two settings.

An advantage of the earnings distribution approach is that it enables researchers to make predictions about the frequency of earnings which is likely caused by the discretionary portion of earnings (McNichols, 2000). Healy and Wahlen (1999) argue that the earnings distribution approach captures the effect of real activities manipulation with cash flow effects such as $R \& D$ or advertising reduction that may not be captured using accrual approaches. This is because, under this approach, instead of accruals, earnings are plotted which contain both accruals and cash flows. In addition, this approach enables researchers to assess the prevalence of earnings management behaviour. Burgstahler and Dichev (1997) provide evidence of the pervasiveness of earnings management to avoid a loss or earnings decrease.

However, some researchers have cast doubt on the idea that earnings management explains the kink. Durtschi and Easton $(2005,2009)$ provide evidence of alternative explanations for discontinuity in earnings distribution including the deflation effect, sample selection criteria, the difference between characteristics of profit and loss observations, and a combination of these explanations. They suggest that because of these effects, the discontinuity pattern cannot be regarded as actual evidence of earnings management. Beaver et al. (2007) indicate that the asymmetric nature of certain earnings components contributes to the discontinuity in earnings distribution. They further demonstrate that higher tax rates for profit firms can push them toward the interval just above zero, and that negative special items push loss firms away from zero. 
In order to determine whether earnings management can explain the kink in the earnings distribution, Dechow et al. (2003) focus on discretionary accruals to examine whether or not small profit firms have higher discretionary accruals compared with two other groups: (1) all other firms and (2) small loss firms. If earnings management is the driver of the kink, it is expected that small profit firms have higher discretionary accruals relative to small loss firms. They argue that small loss firms are expected to have discretionary accruals similar to all other firms since there might be no reason for earnings management to report a smaller loss. Their empirical evidence suggests that small profit firms show higher discretionary accruals than other firms, but small loss firms indicate the same amount of positive discretionary accruals as small profit firms. This is inconsistent with the hypothesis that earnings management causes the kink. They could not confirm that discretionary accruals are the key driver of the anomaly in earnings distribution around zero and recommend caution when using the kink interval as a measure of accruals management. They propose some alternative explanations for the kink including real activities manipulation to shift from reporting a loss to reporting a profit. Building on this finding, Roychowdhury (2006) provides evidence of real activities manipulation by small profit firms. He selects an interval on the immediate right of zero as the most likely to contain firms engaged in earnings management than other firms providing evidence that they manipulate sales, production and expenses to avoid reporting a loss. While Roychowdhury (2006) focuses on earnings management by small profit firms, Siriviriyakul (2013) compares real activities manipulation of small profit and small loss firms and finds no difference between them.

More recent studies have examined the competing hypotheses about drivers of the discontinuity. Donelson et al. (2013) investigate the effect of earnings management on the kink around earnings benchmarks. Using a sample of firms with restated earnings due to an alleged GAAP violation, they plot the earnings of the firms before and after restatement to show 
whether there is a kink around three earnings benchmarks including analysts' forecasts, prior year earnings and zero. At the first two benchmarks, they observe no discontinuity when restated earnings are plotted but they do witness a significant discontinuity when initial earnings are plotted. At zero earnings, they find evidence of discontinuity for both initial and restated earnings. Their evidence is collectively consistent with earnings management around the benchmarks.

There is evidence that good governance could mitigate benchmark-driven earnings management. Dechow et al. (1996) find that a weak governance structure increases the likelihood of earnings management. Klein (2002) indicates that US firms with stronger corporate governance as measured by board and audit committee independence are less engaged in accruals management. Using a sample of firms incorporated in the United Kingdom, Peasnell et al. (2000) provide evidence that earnings management to avoid reporting a loss or earnings decrease has declined in the post-Cadbury period. Bartov and Cohen (2009) investigate benchmark-beating earnings management in the post Sarbanes-Oxley Act era and provide evidence that the frequency of such manipulation has decreased since the passing of the Act. More recently, Gilliam et al. (2015) examine the kink around zero earnings before and after the passing of the Sarbanes-Oxley Act in the US for the period 1976-2012. They observe that the discontinuity is evident in virtually every year before 2002 , i.e. the year in which the Act was passed, but it disappears after the implementation of the Act. They then looked further into other explanations for the kink than earnings management and reported that factors including scaling, selection bias, tax effect and special items could not explain the kink before 2002 and nor could they explain its subsequent disappearance. Overall, their results suggest that the kink cannot be attributed to the non-earnings-management factors suggested by Durtschi and Easton (2005) while they do not provide any compelling evidence on why the kink has disappeared. 
We build on the recent evidence by Gilliam et al. (2015) and investigate earnings management in the vicinity of zero earnings in the aftermath of the kink's disappearance. Upward earnings management by firms with a pre-managed earnings that is just behind an earnings target has been documented by prior studies (e.g. Burgstahler and Dichev, 1997; Degeorge et al., 1999; Burgstahler and Eames, 2006; Roychowdhury, 2006). While there is evidence that beating benchmarks by a narrow margin has decreased in the post-Enron era because the market has become more suspicious of such behaviour (Koh et al., 2008; Bartov and Cohen, 2009), the opportunity to turn a small loss into a small profit by means of earnings manipulation could be still tempting. This is because a firm with a small pre-managed loss can report positive earnings using a slight upward manipulation. The benefits of such manipulation may justify its costs because of its trivial magnitude. We argue that this expectation is still valid in the post-Enron era. Therefore, firms just behind zero earnings are expected push their earnings up in order to shift from a small loss to a small profit. This forms our first hypothesis:

H1: Other things being equal, firms with a small profit exhibit upward earnings management.

The evidence that there is more concern about benchmark-beaters could mean that the market would probably be less worried about the firms that miss earnings benchmarks. This in turn increases the possibility of upward earnings manipulation by firms with a pre-manged loss because they can improve their earnings up to just behind zero earnings. This way they can report a very small loss with less risk of attracting outsiders' attention. Therefore, given the decline in benchmark-beating earnings management (Bartov and Cohen, 2009) and the recent evidence of the disappearance of the discontinuity around zero earnings (Gilliam et al., 2015), we conjecture that the fade of the kink could be, at least to some extent, due to upward earnings management by small loss firms. Such a reduction would narrow the gap between the number of small loss and small profit firms which results in the vanishment of the kink. That being the 
case, it is expected that small loss firms are also involved in income-increasing earnings management, shaping our second research hypothesis:

H2: Other things being equal, firms with a small loss exhibit upward earnings management.

\section{Research Design}

\subsection{Sample}

The sample includes all US firms in DataStream for the period 2002-2011 which amounts to 54,059 firm-year observations. Firm-years with insufficient data and operating in regulated industries (SIC codes 4400-4999) and financial industries (SIC codes 6000-6499) are removed from the sample. Earnings management models are run cross-sectionally for every year and industry, where industries are identified by two-digit SIC codes. In doing so, every industryyear group is required to have at least 15 observations and groups with insufficient observations are deleted. The final sample after considering all these conditions contains 23,524 firm-years with 4,098 unique firms from across 52 industries. All the continuous variables are winsorized at 1 percent in order to reduce the impact of outliers.

\subsection{Measures of Earnings Management}

Cross-sectional models suggested by Roychowdhury (2006), i.e. abnormal cash flows from operations, abnormal production costs and abnormal discretionary expenses, are employed to measure real activities manipulation. These measures have been used very extensively by earnings management studies since their introduction. The residual from the following model is used as abnormal cash flow from operations:

$$
\mathrm{CFO}_{t} / \mathrm{A}_{t-1}=\alpha_{0}+\alpha_{1}\left(1 / \mathrm{A}_{t-1}\right)+\alpha_{2}\left(S_{t} / \mathrm{A}_{t-1}\right)+\alpha_{3}\left(\mathrm{~S}_{t} / \mathrm{A}_{t-1}\right)+\varepsilon_{t}
$$


Where $\mathrm{CFO}_{\mathrm{t}}$ is cash flow from operations in year $t$; $\mathrm{S}_{\mathrm{t}}$ sales in year $t ; \Delta \mathrm{S}_{\mathrm{t}}$ is change in sales from year $t-1$ to year $t$; and $A_{t-1}$ is lagged total assets.

Abnormal discretionary expenses are measured using the following equation:

$$
\mathrm{DE}_{t} / \mathrm{A}_{t-1}=\alpha_{0}+\alpha_{1}\left(1 / \mathrm{A}_{t-1}\right)+\alpha_{2}\left(S_{t-1} / \mathrm{A}_{t-1}\right)+\varepsilon_{t}
$$

Where $\mathrm{DE}_{\mathrm{t}}$ is the sum of $\mathrm{R} \& \mathrm{D}$, advertising, and selling, general and administrative expenses in year $t$.

As Roychowdhury (2006) points out, manipulation of production can affect reported earnings by changing the amount of fixed costs absorbed by each unit of product. He defines production costs as the sum of change in inventory and cost of goods sold and suggests the following model to capture abnormal production costs:

$$
\mathrm{PC}_{t} / \mathrm{A}_{t-1}=\alpha_{0}+\alpha_{1}\left(1 / \mathrm{A}_{t-1}\right)+\alpha_{2}\left(S_{t} / \mathrm{A}_{t-1}\right)+\alpha_{3}\left(\Delta \mathrm{S}_{t} / \mathrm{A}_{t-1}\right)+\alpha_{4}\left(\Delta \mathrm{S}_{t-1} / \mathrm{A}_{t-1}\right)+\varepsilon_{t}
$$

Where $\mathrm{PC}_{\mathrm{t}}$ is production costs in year $t$ and $\Delta \mathrm{S}_{\mathrm{t}-1}$ is change in sales from year $t-2$ to year $t-1$.

Finally, Jones model (1991) is run to measure accruals management:

$$
\mathrm{AC}_{t} / \mathrm{A}_{t-1}=\alpha_{0}+\alpha_{1}\left(1 / \mathrm{A}_{t-1}\right)+\alpha_{2}\left(\Delta S_{t} / \mathrm{A}_{t-1}\right)+\alpha_{3}\left(\mathrm{PPE}_{t} / \mathrm{A}_{t-1}\right)+\varepsilon_{t}
$$

Where $\mathrm{AC}_{\mathrm{t}}$ is the total accruals defined as the difference between earnings and cash flow from operations in year $t$ and $\mathrm{PPE}_{\mathrm{t}}$ is gross property, plant, and equipment in year $t$.

Dechow et al. (1995) argue that Jones (1991) model ignores the possibility that revenue itself might be manipulated, and suggest that change in receivables should be deducted from change in revenues in the accruals model. To examine whether or not the results are sensitive to the 
use of the modified Jones model, the following regression is also run to measure accruals management:

$$
\mathrm{AC}_{t} / \mathrm{A}_{t-1}=\alpha_{0}+\alpha_{1}\left(1 / \mathrm{A}_{t-1}\right)+\alpha_{2}\left(\left[\Delta S_{t}-\Delta R E C_{t}\right] / \mathrm{A}_{t-1}\right)+\alpha_{3}\left(\mathrm{PPE}_{t} / \mathrm{A}_{t-1}\right)+\varepsilon_{t}
$$

Where $\triangle \mathrm{REC}_{\mathrm{t}}$ is net receivables in the year $t$ less net receivables in year $t-1$.

\subsection{Empirical Model}

In order to test whether, and to what extent, firms in the intervals to the right and left of zero are involved in earnings management, each measure of earnings management is separately regressed on an indicator variable that denotes if the observation belongs to the interval in question. To this end, the following pooled cross-sectional model ${ }^{1}$ with a year indicator variable is run:

$$
E M_{t}=\alpha+\alpha_{1}(S I Z E)_{t-1}+\alpha_{2}(M T B)_{t-1}+\alpha_{3}(N I)_{t}+\alpha_{4}(\text { INTERVAL })_{t}+\sum_{j} \alpha_{5, j} \text { Year }_{j}+
$$

$\varepsilon_{t} \quad(6)$

Where EM is the earnings management measure and INTERVAL is an indicator variable that is set equal to 1 if the observation belongs to the interval suspected of manipulation and 0 otherwise. Equation (6) is separately run for the intervals to the right and left of zero to test the research hypotheses. When testing $H 1$ (small profit firms) INTERVAL is set to be 1 if the observation belongs to the interval to the immediate right of zero earnings, and when testing H2 (small loss firms) it is set to be 1 if the observation belongs to the interval to the immediate left of zero.

\footnotetext{
${ }^{1}$ Consistent with Roychowdhury (2006) and Zang (2012), pooled cross sectional regression is used because this study examines independent observations that exhibit a certain behaviour, i.e. firm-years that have reported a small profit or a small loss, and compare them with the rest of observations.
} 
Following Roychowdhury (2006) and Zang (2012), size, growth and performance are controlled for. SIZE is the logarithm of the lagged market value of equity, MTB is lagged market to book ratio, and NI is net income before extraordinary items scaled by lagged assets. Although there are well-known exceptions, large firms, compared with small firms, are generally expected to have less earnings management since they tend to have stronger corporate governance systems in place (e.g. better internal control and bigger auditors) which makes earnings management more costly for them. Thus, the coefficient on SIZE is expected to be negative. Performance is controlled for using the return on assets ratio. Dechow et al. (1995) argue that earnings management models that ignore performance may be biased and that not considering performance may interfere with statistical inferences from earnings management models. Since by definition net income is the sum of operating cash flows and accruals, it is expected that $N I$ is positively related to abnormal operating cash flows and abnormal accruals. Firms in different stages of the business cycle vary by future growth opportunities. Firms with a high growth rate are expected to have a higher working capital and are also more likely to engage in earnings management (McNichols, 2000). Therefore, the variation in earnings management measures that is attributable to growth is not discretionary and should be controlled for (Collins et al., 2017). Growth firms are expected to have growing positive income and hence are not expected to be in the vicinity of zero earnings which would result in a negative coefficient on $M T B$.

\section{Results}

\subsection{Earnings Distribution around Zero}

Figure 1 illustrates the distribution of net income scaled by lagged assets with an interval width of 0.005 for the range -0.25 to +0.35 (120 intervals). Lagged assets are used to scale earnings 
so that any anomaly around zero could not be attributed to market capitalisation (Roychowdhury, 2006). As can be seen in the figure, there is no obvious discontinuity around zero. When the number of observations in the intervals are considered, as Burgstahler and Dichev (1997) suggest, the normal frequency of observations in each interval is expected to be the average of the number of observations in its two adjacent intervals. The number of observations in the interval to the immediate right of zero is 352 which is very close to the average number of observations in the intervals just before and after the interval to the immediate right of zero i.e. 363.5 . This signifies the lack of anomaly around zero and is in agreement with the results reported by Gilliam et al. (2015) who suggest that the discontinuity around zero has disappeared in the post-Enron era.

\section{[Insert Figure 1 here]}

The descriptive statistics presented in Table 1 compare firms in the intervals left and right of zero with the rest of the sample. When total assets and the market value of equity are considered, small loss firms are smaller in size than both the rest of the sample and small profit firms. Interestingly, small loss firms also show higher cash flow from operations, production costs and discretionary expenses. However, the difference between small loss and small profit firms disappears when the variables are scaled by total assets which suggests that the difference between the two groups could be attributable to their size. In terms of market to book value, both groups are quite similar and represent substantially lower growth than the rest of the sample. Total accruals for the whole sample is negative and this is also the case for small loss and small profit firms; while small loss firms show substantially more absolute numbers than small profit firms which again could be attributable to their size as the difference is not observed when scaled levels are compared.

[Insert Table 1 here] 


\subsection{Comparison of Intervals Right and Left of Zero}

This section examines whether firms located in the vicinity of zero earnings are engaged in upward manipulation of earnings. Figure 2 provides a closer look at the intervals around zero earnings. The intervals are defined with the width of 0.005 for the range of -0.075 to +0.075 (30 intervals). This is consistent with the methodology taken by Roychowdhury (2006) to select observations suspected of earnings management; however, instead of only focusing on the right of zero, we examine earnings management for firm-years located in the two intervals left and right of zero (separated by the dashed line). Based on this, 432 firm-years are located in the interval to the immediate right of zero and 352 firm-years are located in the interval to the immediate left of zero.

[Insert Figure 2 here]

Equation (6) is run separately for each of the five measures of earnings management, i.e. abnormal cash flow from operations, abnormal production costs, abnormal discretionary expenses and abnormal accruals using Jones and modified Jones models. Table 2 reports the results of the main regression model for observations in the two intervals left and right of zero. Consistent with the research hypotheses, abnormal production costs indicate income-increasing earnings management by both small loss and small profit firms as the coefficient on INTERVAL is positive and significant for both groups. As Roychowdhury (2006) points out, firms can overproduce to allocate their fixed production overheads over a larger number of units which results in an equivalent decrease in fixed cost absorbed by each unit sold and hence an increase in earnings. The result for discretionary expenses is also in agreement with upward earnings management predicted in $\mathrm{H} 1$ and $\mathrm{H} 2$ as both intervals have abnormally lower discretionary expenses compared with the rest of the sample. Likewise, albeit of much less magnitude, the coefficient for accruals is generally suggestive of similar income-increasing manipulation by 
both groups. This is comparable to the results reported by Dechow et al. (2003) that small loss firms indicate the same amount of positive discretionary accruals as small profit firms. The magnitude and significance of accruals management in the right of zero is greater than the left of zero. This is consistent with Barua et al. (2006) who indicate that profit firms are more likely to use accruals management than loss firms. However, the negative coefficients for abnormal cash flow from operations, which are marginally significant, are not in line with incomeincreasing manipulation predicted by the research hypotheses as firms located in both intervals exhibit abnormally lower cash flow from operations than the rest of observations. This could be due to the prominent inverse relationship between discretionary accruals and cash flow from operations (Dechow et al., 1995) since "positive accruals increasingly are necessary to meet an earnings target as operating cash flows diminish" (Houmes and Skantz, 2010, p. 63). The results for the control variables are generally consistent with our expectations as SIZE and MTB show a negative sign for most of the measures and $N I$ is positively associated with abnormal accruals and abnormal cash flow from operations.

The results for the interval right of zero is also consistent with those of Roychowdhury (2006) who examine income-increasing real activities manipulation by firms that narrowly beat the zero earnings benchmark. However, he hypothesises that suspect observations are expected to show an unusually low cash flow from operations while given the direct relationship between earnings and cash flows from operations, any income-increasing earnings management is expected to result in an unusually high cash flow from operations and an inverse relationship cannot be interpreted as a sign of upward manipulation. Abnormally lower cash flow from operations of firms around zero earnings could be due to their operational features which needs further investigation. In any case, the coefficients on the two other measures of real activities manipulation, namely abnormal production costs and abnormal discretionary expenses, are considerably larger than those of accruals management measures. This is in line with the 
findings of Cohen et al. (2008) that suggest a recent shift from accruals management to real activities manipulation in the aftermath of the Sarbanes-Oxley Act. By and large, interestingly enough, both small profit firms and small loss firms show very similar earnings management behaviour which indicates that the methodology taken by prior studies comparing the two groups to infer earnings management could lead to false conclusions.

[Insert Table 2 here]

\subsection{Earnings Distribution around Earnings Change}

While Gilliam et al. (2015) only examine the prominent discontinuity around zero earnings, this paper, in addition to reporting corroborative evidence on zero earnings discontinuity, provides fresh evidence on the previously observed discontinuity in the distribution of earnings change (Burgstahler and Dichev, 1997). Figure 3 shows the distribution of change in net income scaled by lagged assets with an interval width of 0.005 for the range -0.25 to +0.35 (120 intervals). In line with the evidence on the disappearance of zero earnings discontinuity, the figure indicates that there is no obvious discontinuity around earnings change either. The number of observations in the interval to the immediate right of zero earnings change is 1030 which is close to the average number of observations in the two neighbouring intervals i.e. 1055. The symmetric distribution of earnings change is similar to that of earnings which demonstrates that the discontinuity around zero earnings change has also disappeared in the post-Enron era. These results are consistent with the expectation that beating benchmarks by a small margin has declined in the post-Enron era as the market has become more suspicious of such behaviour (Koh et al., 2008).

[Insert Figure 3 here] 
Table 3 compares firms in the intervals left and right of zero earning change with the rest of the sample. Both firms with a small increase and a small decrease in earnings are generally larger than the rest of the sample and show lower growth. This implies that larger, more mature firms report more stable financial results. And while firms with a small decrease in earnings are generally larger, both groups show very similar cash flow from operations, production costs, discretionary expenses and accruals when the items are scaled by total assets.

\section{[Insert Table 3 here]}

\subsection{Comparison of Intervals Right and Left of Zero Earnings Change}

This section explores whether and how firms located in the vicinity of zero change in earnings are involved in earnings management. Equation (6) is re-run to compare earnings management of firms located in the interval to the immediate right (left) of zero change with the rest of the sample, with INTERVAL being equal to 1 if the observation belongs to the group of firms with a small increase (decrease) in earnings and zero otherwise. The model is separately run for each of the five earnings management measures. The results reported in Table 4 are generally comparable to those of firms neighbouring zero earnings. Both groups indicate incomeincreasing earnings management as the coefficient on INTERVAL is significant and positive for abnormal production costs and accruals and negative for abnormal discretionary expenses. The results for abnormal cash flows from operations lack significance. Similar to small profit firms and small loss firms which both exhibit consistent upward earnings management, the analogous results for firms located to the right and left of zero earnings change further indicate that comparing the two groups to draw inferences with regards to earnings management could be misleading. It also suggests that firms that just miss their last year earnings could be as likely to be engaged in earnings management as those beating their last year performance by a small margin. 
[Insert Table 4 here]

\subsection{Alternative Definition of Earnings Intervals}

Earnings distribution studies tend to merely focus on one interval, i.e. the one just above an earnings target, while other intervals may also contain earnings management. Jacob and Jorgensen (2007, p. 388) note that "earnings management is not confined to the immediate vicinity of earnings thresholds but is discernible over broader sections of earnings and earnings change histograms". Partial identification of firms likely to be engaged in earnings management weakens the power of tests. To examine whether the results are sensitive to the interval width used in this study to pick firms suspected of earnings manipulation, instead of the interval width prevalent in the literature (i.e. 0.005) which was applied in the initial results, double the initial width is used and Equation (6) is re-run for both firms located in the intervals to the right and left of zero earnings. Figure 4 shows the intervals based on the width of 0.01 . The revised width more than doubles the number of observations sitting in the two intervals of interest as the number of observations in the interval to the right and left of zero rises to 1006 and 784 , respectively.

[Insert Figure 4 here]

Table 5 reports the results when the width of earnings intervals is 0.01 . For firms reporting a small profit, the coefficients on the variable of interest, i.e. INTERVAL, shows dramatic improvement in terms of both significance and magnitude when they are compared with the initial results. The results for small loss firms are also consistent with the initial findings yet the magnitude of the coefficients generally declines. While this suggests that firms located in a wider area around zero are engaged in income-increasing earnings management, manipulators with a small loss seems to be more densely located in the vicinity of zero earnings 
than those with a small profit. In any case, these findings indicate that widening the width of intervals can generally improve the power of the tests.

[Insert Table 5 here]

\section{Discussion and Conclusion}

This study provides more insight into a recent finding by Gilliam et al. (2015) concerning the disappearance of zero-earnings discontinuity after the passage of the Sarbanes-Oxley Act. We suggest that benchmark-beating earnings management could have contributed to the disappearance of the discontinuity. Given the evidence that benchmark-driven manipulation has decreased due to the recent market scepticism about beating benchmarks by a slight margin (Koh et al., 2008; Bartov and Cohen, 2009) which implies less attention is attracted by firms that miss earnings benchmarks, firms with a pre-manged loss or earnings decrease could enjoy a quiet room to improve their earnings up to just behind earnings benchmarks. That is, restricting benchmark-beating earnings management could have two effects: (1) a decrease in the frequency of beating benchmarks by a small margin, and (2) an increase in the frequency of missing benchmarks by a small margin. This in turn could narrow the gap between the number of small profit and small loss firms resulting in the fade of the discontinuity. Therefore, the disappearance of the discontinuity could be due to upward earnings management by small loss firms. Our findings are consistent with this and suggest further that small loss firms and small profit firms show a very similar earnings management behaviour both in terms of accruals management and real activities manipulation. This finding also explains why prior studies could not find any significant difference between accruals management of small profit and small loss firms (Dechow et al., 2003). Despite the prevalent notion in the literature that small loss firms are less likely to manipulate earnings, they are actually not. In other words, failure to document a difference between firms to the right and left of zero is not due to small 
profit firms not managing their earnings, but it is instead due to small loss firms being similarly engaged in upward manipulation. Thus, comparing small profit firms and small loss firms to infer earnings management could lead to false conclusions. Furthermore, the disappearance of the kink should not be interpreted as a sign of no earnings management by firms around zero earnings since they are involved in upward manipulation. Another implication of our study for future research on benchmark-driven earnings management is that while researcher have traditionally focused on the interval just to the right of earnings targets, they should look into both sides in the vicinity of earnings targets and use wider intervals. Moreover, this paper provides new evidence on earnings management to avoid earnings decreases, suggesting that the prominent discontinuity around zero earnings change, observed by Burgstahler and Dichev (1997), has also recently disappeared. We show that firms reporting small earnings decreases exhibit similar earnings management behaviour to those with small earnings increases indicating that comparing the firms located around zero earnings change could also lead to false earnings management inferences.

The fact that earnings management is observed in both presence and absence of the kink calls into question that the kink was initially created by earnings management. Therefore, the disappearance of the kink should not be interpreted as no earnings management by firms located in the vicinity of zero earnings and zero change in earnings. While the main driver of the discontinuity in the earnings distribution remains an open question, our results suggest that the users should be more mindful of firms that narrowly miss benchmarks as they are likely to manipulate their earnings in the quiet room created by fixation on benchmark-beaters. While prior studies (e.g. Koh et al., 2008; Bartov and Cohen, 2009) suggest that the market have become more vigilant of marginal benchmark-beaters, shareholders, analysts and auditors should also pay special attention to firms marginally missing earnings targets since they could also be engaged in earnings manipulation. 


\section{References}

Baker, T., Collins, D., and Reitenga, A. (2003). "Stock-option compensation and earnings management incentives." Journal of Accounting, Auditing and Finance, Vol. 18, No. 4, pp. 557-582.

Bartov, E. and Cohen, D. A. (2009). "The "number games" in the pre- and post-SarbanesOxley eras", Journal of Accounting, Auditing \& Finance, Vol. 24, No. 4, pp. 505-534.

Barua, A., J. Legoria, and J. S. Moffitt. (2006). "Accruals management to achieve earnings benchmarks: A comparison of pre-managed profit and loss firms", Journal of Business Finance \& Accounting, Vol. 33, No. 5, pp. 653-670.

Beatty, A., Chamberlain, S. L., and Magliolo, J. (1995). "Managing financial reports of commercial banks: the influence of taxes, regulatory capital, and earnings", Journal of Accounting Research, Vol. 33, pp. 231-261.

Beaver, W. H., McNichols, M. F., and Nelson, K. K. (2003), "Management of the loss reserve accrual and the distribution of earnings in the property-casualty insurance industry", Journal of Accounting and Economics, Vol. 35, pp. 347-376.

Beaver, W. H., McNichols, M. F., and Nelson, K. K. (2007), "An alternative interpretation of the discontinuity in earnings distributions", Review of Accounting Studies, Vol. 12 No. 4, pp. 525-556.

Burgstahler, D. and Dichev, I. (1997), "Earnings management to avoid earnings decreases and losses", Journal of Accounting and Economics, Vol. 24, No. 1, pp. 99-126.

Burgstahler, D. C., and Eames, M. (2006). "Management of earnings and analysts' forecasts to achieve zero and small positive earnings surprises", Journal of Business Finance \& Accounting, Vol. 33, pp. 633-652.

Burgstahler, D., and Chuk, E. (2015), "Do Scaling and Selection Explain Earnings Discontinuities?", Journal of Accounting and Economics, Vol. 60, pp. 168-186.

Cheng, Q., and Warfield, T.D. (2005). "Equity Incentives and Earnings Management", The Accounting Review, Vol. 80, No. 2, pp. 441- 476.

Cohen, D., Dey, A., and Lys, T. (2008), "Real and accrual-based earnings management in the pre- and post-Sarbanes-Oxley periods", The Accounting Review, Vol. 83, pp. 757787.

Collins, D. W., Pungaliya, R. S., and Vijh, A. M. (2017). "The Effects of Firm Growth and Model Specification Choices on Tests of Earnings Management in Quarterly Settings", The Accounting Review, Vol. 92, No. 2, pp. 69-100.

Das, S., Shroff, P. K., and Zhang, H. (2009). "Quarterly earnings patterns and earnings management”, Contemporary Accounting Research, Vol. 26, No. 3, pp. 797-831.

Daske, H., Gebhardt, G. and McLeay, S. (2006). "The distribution of earnings relative to targets in the European Union", Accounting and Business Research, Vol. 36, No. 3, pp. 137167. 
Dechow, P., Sloan, R., and Sweeney, A. (1995). "Detecting earnings management", The Accounting Review, Vol. 70, pp. 193-225.

Dechow, P., Sloan, R., and Sweeney, A. (1996). "Causes and Consequences of Earnings Manipulations: An Analysis of Firms Subject to Enforcement Actions by the SEC", Contemporary Accounting Research, Vol. 13, No. 1, pp. 1-36.

Dechow, P.M., Richardson, S.A., and Tuna, I. (2003), “Why are earnings kinky?”, Review of Accounting Studies, Vol. 8, pp. 355-384.

DeFond, M. L. and Jiambalvo, J. (1994). "Debt covenant violation and manipulation of accruals", Journal of Accounting and Economics, Vol. 17, No. 1-2, pp. 145-176.

Degeorge, F., Patel, J., and Zeckhauser, R. (1999), "Earnings Management to Exceed Thresholds", Journal of Business Finance \& Accounting, Vol. 72, No. 1, pp. 1-33.

Dichev, I. and Skinner, D. J. (2002). "Large-sample evidence on the debt covenant hypothesis", Journal of Accounting Research, Vol. 40, pp. 1091-1123.

Donelson, D., McInnis, J., and Mergenthaler, R. (2013), "Discontinuities and earnings management: evidence from restatements related to securities litigation", Contemporary Accounting Research, Vol. 30, pp. 242-268.

Durtschi, C., and Easton, P. (2005), "Earnings management? The shapes of the frequency distributions of earnings metrics are not evidence ipso facto", Journal of Accounting Research, Vol. 43, pp. 557-592.

Durtschi, C., and Easton, P. (2009), "Earnings management? Erroneous inferences based on earnings frequency distributions", Journal of Accounting Research, Vol. 47, pp. 12491281.

Ewert, R., and Wagenhofer, A. (2005), "Economic Effects of Tightening Accounting Standards to Restrict Earnings Management", The Accounting Review, Vol. 43, No. 4, pp. $1101-1124$.

Garcia-Meca, E. and Sanchez-Ballesta, J. P. (2009), "Corporate governance and earnings management: A meta-analysis", Corporate Governance: An International Review, Vol. 17, pp. 594-610.

Gilliam, T. A., Heflin, F., and Paterson, J. S. (2015), "Evidence that the zero-earnings discontinuity has disappeared", Journal of Accounting and Economics, Vol. 60, pp. 117-132.

Gunny, K. (2010). "The relation between earnings management using real activities manipulation and future performance: Evidence from meeting earnings benchmarks", Contemporary Accounting Research, Vol. 27, No. 3, pp. 1-34.

Gupta, M., Khurana, I., and Pereira, R. (2008). "Legal enforcement, short maturity debt, and the incentive to manage earnings", Journal of Law and Economics, Vol. 51, pp. 619639. 
Halaoua, S., Hamdi, B., \& Mejri, T. (2017). "Earnings management to exceed thresholds in continental and Anglo-Saxon accounting models: The British and French cases", Research in International Business and Finance, Vol. 39, pp. 513-529.

Hansen, J. (2010), "The effect of alternative goals on earnings management studies: an earnings benchmark examination", Journal of Accounting and Public Policy, Vol. 29, pp. 459480 .

Hayn, C. (1995), "The information content of losses", Journal of Accounting and Economics, Vol. 20, pp. 125-153.

Healy, P. M. (1985). "The effect of Bonus schemes on accounting decisions", Journal of Accounting and Economics, Vol. 7, No. 1-3, pp. 85-107.

Healy, P. M., and Whalen, J. M. (1999), “A review of the earnings management literature and its implications for standard setting”, Accounting Horizons, Vol. 13, No. 4, pp. 36583.

Holthausen, R.W. (1990), "Accounting method choice: opportunistic behavior, efficient contracting and information perspectives", Journal of Accounting and Economics, Vol. 12, pp. 207-218.

Houmes, R. E., and Skantz, T. R. (2010), "Highly Valued Equity and Discretionary Accruals", Journal of Business Finance \& Accounting, Vol. 37, pp. 60-92.

Jacob, J., and Jorgensen, B. (2007), "Earnings management and accounting income aggregation", Journal of Accounting and Economics, Vol. 43, pp. 369-390.

Jones, J. (1991), "Earnings management during import relief investigations", Journal of Accounting Research, Vol. 29, No. 2, pp. 193-228.

Kahneman, D., Tversky, A. (1979), "Prospect theory: an analysis of decision under risk", Econometrica, Vol. 47, pp. 263-291.

Kerstein, J., and Rai, A. (2007), "Intra-Year Shifts in the Earnings Distribution and their Implications for Earnings Management", Journal of Accounting and Economics, Vol. 44, pp. 399-419.

Kim, J. B., and Sohn, B. C. (2013). "Real earnings management and cost of capital", Journal of Accounting and Public Policy, Vol. 32, No. 6, pp. 518-543.

Klein, A. (2002). "Audit committee, board of director characteristics", and earnings management, Journal of Accounting and Economics, Vol. 33, pp. 375-400.

Koh, K., Matsumoto, D., and Rajgopal, S. (2008), "Meeting or beating analyst expectations in the post-scandals world: changes in stock market rewards and managerial actions", Contemporary Accounting Research, Vol. 25, No. 4, pp. 1067-1098.

Leventis, S. and Dimitropoulos, P. (2012), "The role of corporate governance in earnings management: experience from US banks", Journal of Applied Accounting Research, Vol. 13, No. 2, pp. 161-177. 
Lobo, G., and Zhou, J. (2010), "Changes in discretionary financial reporting behaviour following the Sarbanes-Oxley Act", Journal of Auditing Accounting and Finance, Vol. 25, pp. 1-26.

McNichols, M. F. (2000), "Research Design Issues in Earnings Management Studies”, Journal of Accounting and Public Policy, Vol. 19, No. 4-5, pp. 313-345.

Neifar, S., Halioui, K., and Ben Abdelaziz, F. (2016), "The motivations of earnings management and financial aggressiveness in American firms listed on the NASDAQ 100”, Journal of Applied Accounting Research, Vol. 17, No. 4, pp. 397-420.

Peasnell, K. V., Pope P. F., and Young, S. (2000), "Accrual Management to Meet Earnings Targets: U.K. Evidence Pre-and Post-Cadbury”, British Accounting Review, Vol. 32, pp. 415-445.

Petroni, K. R. (1992). "Optimistic reporting in the property casualty insurance industry", Journal of Accounting and Economics, Vol. 15, pp. 485-508.

Roychowdhury, S. (2006), "Earning Management through real activities manipulation", Journal of Accounting and economics, Vol. 42, No. 3, pp. 335-370.

Siriviriyakul, S. (2013), "Re-examining real earnings management to avoid losses", Working paper, University of California.

Skinner, D. (1993). “The investment opportunity set and accounting procedure choice: Preliminary evidence", Journal of Accounting and Economics, Vol. 16, No. 4, pp. 407-445.

Strobl, G. (2013), "Earnings Manipulation and the Cost of Capital", Journal of Accounting Research, Vol. 51, No. 2, pp. 449-73.

Sweeney, A. P. (1994). "Debt-covenant violations and managers' accounting responses", Journal of Accounting and Economics, Vol. 17, No. 3, pp. 281-308.

Van Caneghem, T. (2002), "Earnings management induced by cognitive reference points", British Accounting Review, Vol. 34, No. 2, pp. 46-57.

Walker, M. (2013). "How far can we trust earnings numbers? What research tells us about earnings management.", Accounting and Business Research, Vol. 43, No. 4, pp. 445481.

Zang, A. Y. (2012), "Evidence on the trade-off between real activities manipulation and accrual-based earnings management", The Accounting Review, Vol. 87, No. 2, pp. 675-703. 


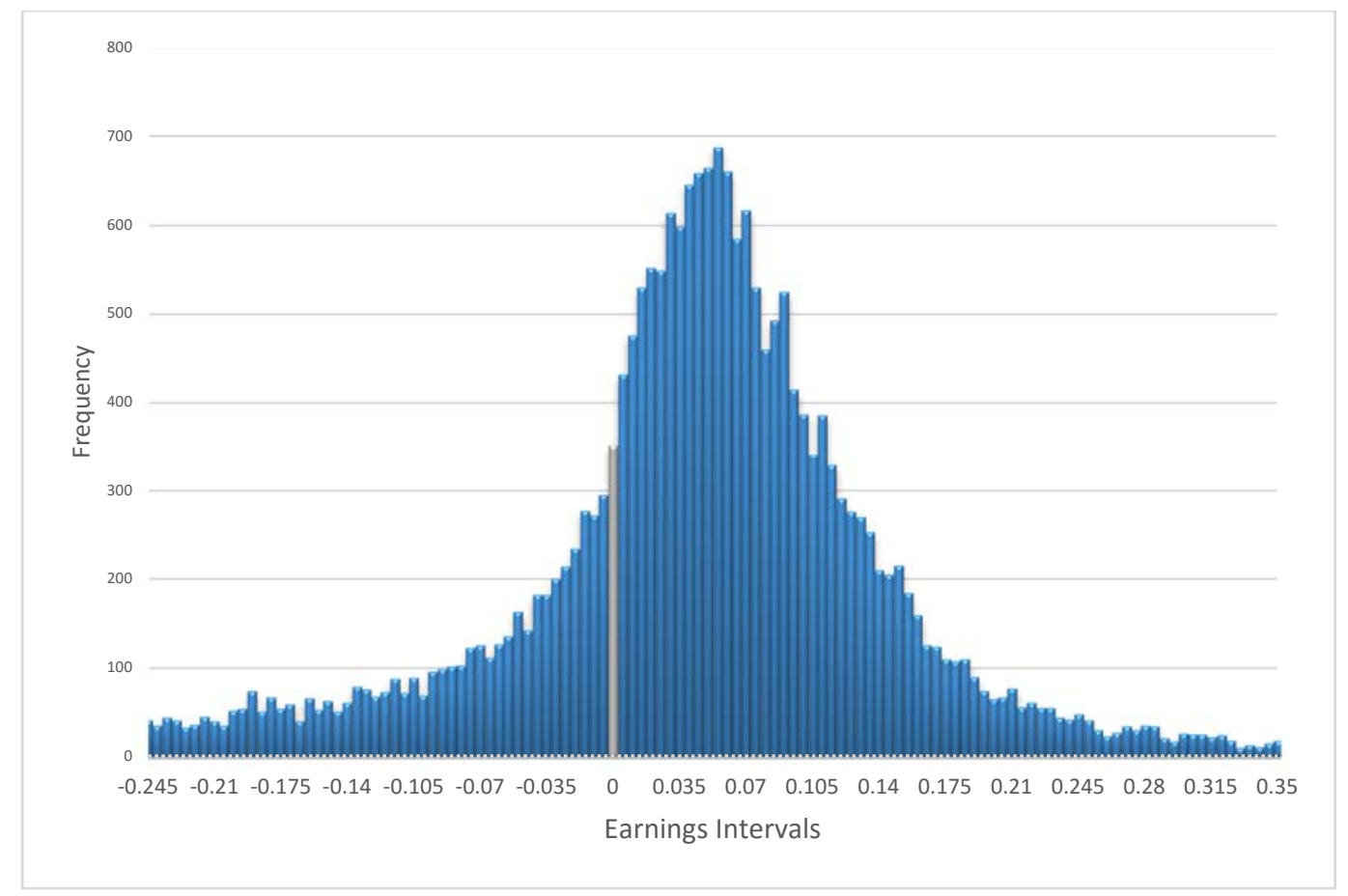

Figure 1. Distribution of earnings intervals. 23,524 firm-years are grouped into 120 earnings intervals with a width of 0.005 for the range from -0.25 to +0.35 . Earnings are defined as net income before extraordinary items scaled by lagged total assets. 


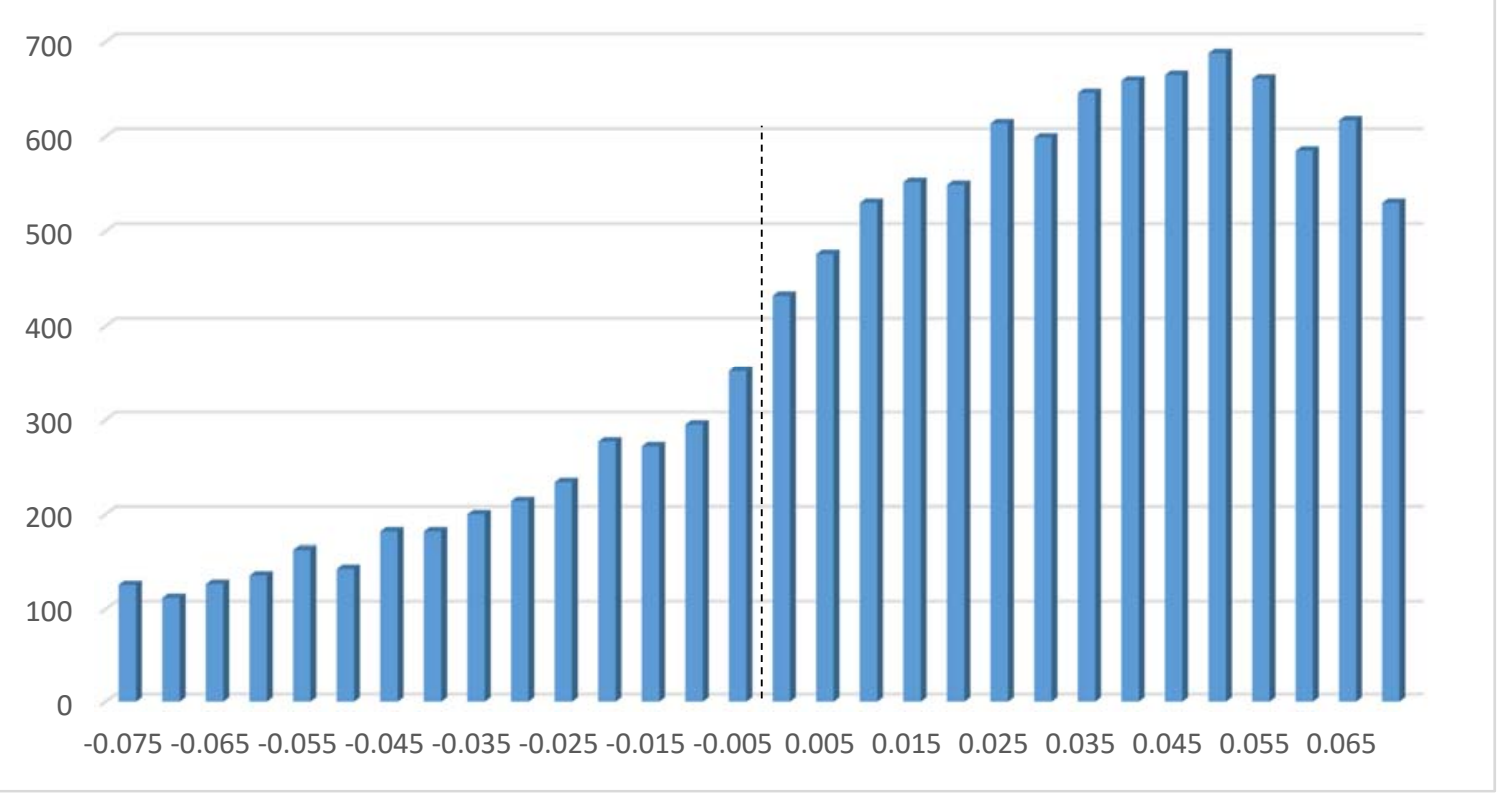

Figure 2. Frequency of observations around zero earnings. Firm-years are grouped into 30 earnings intervals with the width of 0.005 for the range from -0.075 to +0.075 . 


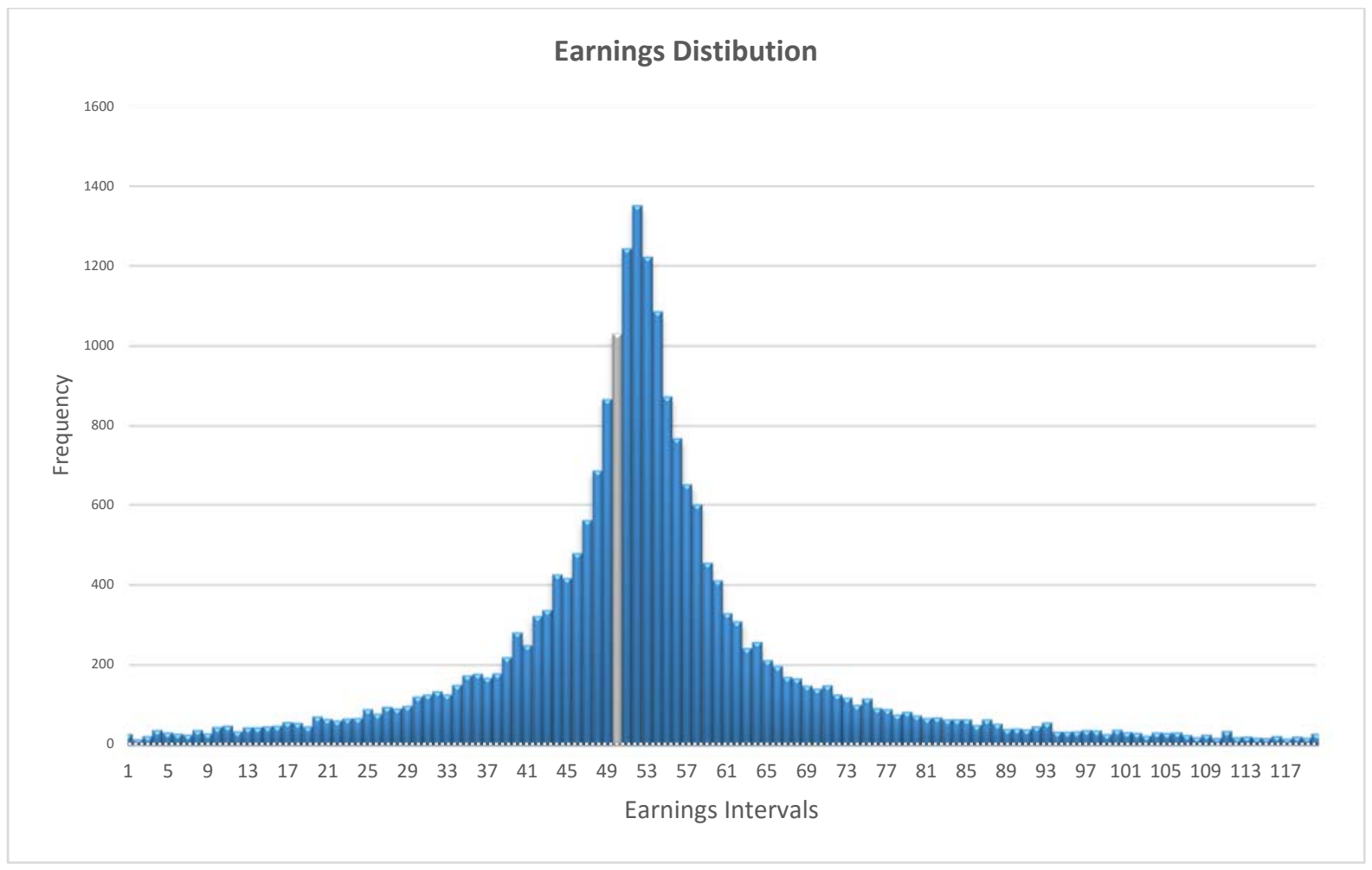

Figure 3. Distribution of change in annual earnings. 23,524 firm-years are grouped into 120 intervals with the width of 0.005 for the range from -0.25 to +0.35 . Change in earnings is defined as the difference between current and last year net income before extraordinary items scaled by lagged total assets. 


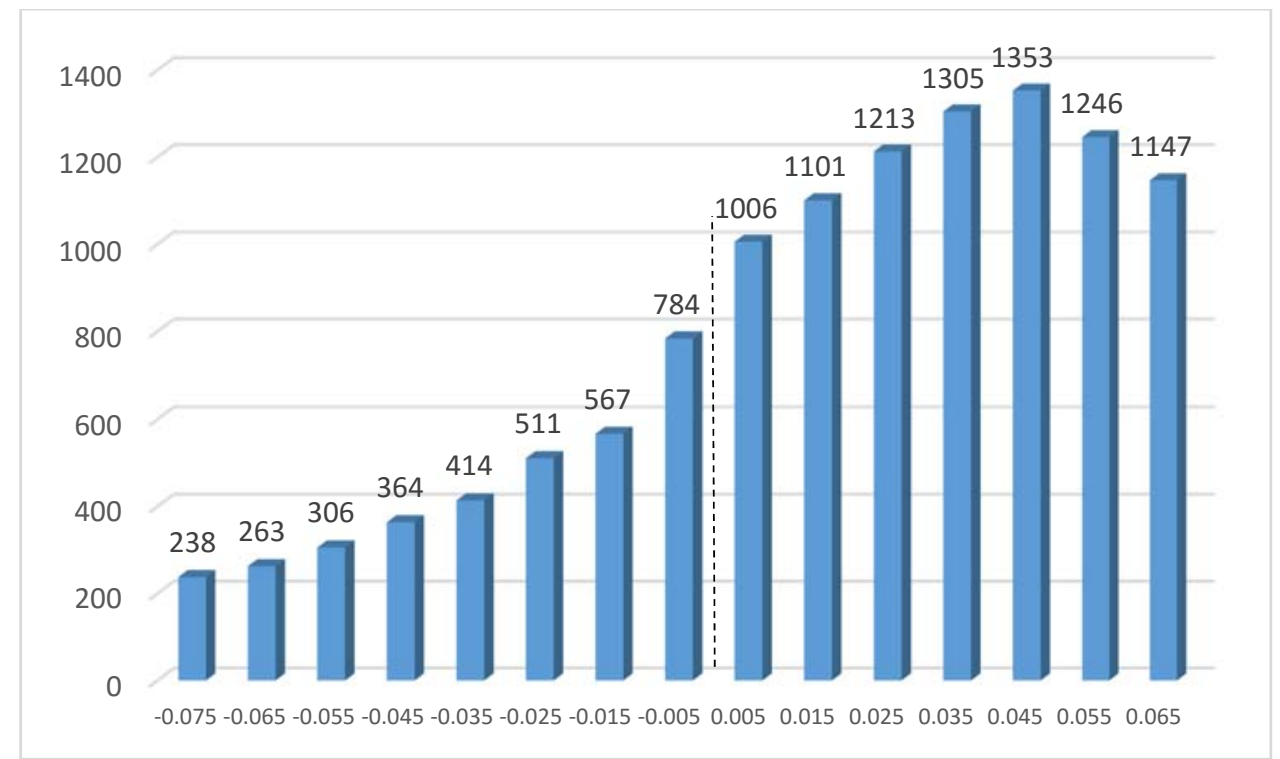

Figure 4. Frequency of observations around zero earnings using alternative definition of intervals. Firm-years are grouped into 15 earnings intervals with the width of 0.01 for the range from -0.075 to +0.075 . 
Table 1: Descriptive Statistics for Zero Earnings

\begin{tabular}{|c|c|c|c|c|c|c|c|c|c|c|}
\hline \multirow{3}{*}{ Variable } & \multirow{2}{*}{\multicolumn{2}{|c|}{ Whole sample }} & \multicolumn{4}{|c|}{ Left of Zero } & \multicolumn{4}{|c|}{ Right of Zero } \\
\hline & & & \multicolumn{2}{|c|}{ Small Loss Firms } & \multicolumn{2}{|c|}{ Rest of Sample } & \multicolumn{2}{|c|}{$\begin{array}{l}\text { Small Profit } \\
\text { Firms }\end{array}$} & \multicolumn{2}{|c|}{ Rest of Sample } \\
\hline & Mean & Median & Mean & Median & Mean & Median & Mean & Median & Mean & Median \\
\hline $\begin{array}{l}S \text { (\$ } \\
\text { million) }\end{array}$ & 7277.39 & 312.43 & 12900 & 464.38 & 7192.76 & 309.37 & 5838.69 & 310.72 & 7304.31 & 312.50 \\
\hline $\begin{array}{l}\boldsymbol{A}(\$ \\
\text { million) }\end{array}$ & 7553.19 & 419.03 & 15200 & 796 & 7437.54 & 413.64 & 7379.62 & 626.63 & 7556.44 & 414.85 \\
\hline $\begin{array}{l}M V \$ \\
\text { (million) }\end{array}$ & 2923.45 & 365.09 & 1654.05 & 349.78 & 2942.68 & 365.22 & 1317.42 & 257.37 & 2953.50 & 367.07 \\
\hline MTB & 3.25 & 1.74 & 1.68 & 1.18 & 3.27 & 1.75 & 1.66 & 1.18 & 3.28 & 1.76 \\
\hline $\begin{array}{l}C F O(\$ \\
\text { million) }\end{array}$ & 635.02 & 30.70 & 728.80 & 30.66 & 633.60 & 30.72 & 410.01 & 26.63 & 639.23 & 30.80 \\
\hline $\begin{array}{l}P C(\$ \\
\text { million) }\end{array}$ & 4847.36 & 180.64 & 8787.05 & 265.67 & 4788.57 & 179.10 & 4468.75 & 178.52 & 4854.21 & 180.683 \\
\hline $\begin{array}{l}D E(\$ \\
\text { million) }\end{array}$ & 1421.62 & 65.52 & 2659.44 & 83.34 & 1403.01 & 65.37 & 1105.26 & 48.08 & 1427.37 & 65.77 \\
\hline $\begin{array}{l}A C(\$ \\
\text { million) }\end{array}$ & -294.33 & -15.31 & -756.94 & -32.91 & -287.32 & -15.02 & -391.93 & -25.32 & -292.51 & -15.15 \\
\hline $\begin{array}{l}\text { NI (\$ } \\
\text { million) }\end{array}$ & 340.55 & 10.72 & -28.14 & -1.61 & 346.13 & 11.64 & 18.09 & 1.00 & 346.58 & 11.49 \\
\hline$S / A$ & 1.13 & 0.91 & 0.91 & 0.67 & 1.13 & 0.92 & 0.89 & 0.72 & 1.13 & 0.91 \\
\hline CFO/A & 0.07 & 0.085 & 0.052 & 0.051 & 0.07 & 0.086 & 0.055 & 0.052 & 0.07 & 0.09 \\
\hline PC/A & 0.80 & 0.57 & 0.71 & 0.45 & 0.80 & 0.57 & 0.69 & 0.49 & 0.80 & 0.57 \\
\hline$D E / A$ & 0.32 & 0.24 & 0.21 & 0.16 & 0.33 & 0.24 & 0.24 & 0.16 & 0.33 & 0.25 \\
\hline$A C / A$ & -0.07 & -0.054 & -0.054 & -0.054 & -0.07 & -0.054 & -0.053 & -0.049 & -0.07 & -0.05 \\
\hline
\end{tabular}

* This table presents the mean, median and standard deviation of the variables used in the models for small loss and small profit firms and the rest of the sample as well as the whole sample.

** To lessen the effect of outliers, all of the continuous variables are winsorized at 1 percent tails.

$* * *$ Variable definitions:

$\boldsymbol{S}=$ net sales or revenue

$\boldsymbol{A}=$ total assets

$M V=$ market value of equity

$\mathbf{M T B}=$ market to book ratio in current year

$\boldsymbol{C F O}=$ cash flow from operations

$P C=$ production costs for year $t$ as the sum of inventory change and cost of goods sold

$\boldsymbol{D E}=$ discretionary expenses as sum of selling, general, and administrative expenses, advertising expenses, and research and development expenses

$A C=$ total accruals as net income before extraordinary items minus cash flow from operations

$N I=$ net income before extraordinary items 
Table 2: Comparison of Intervals Right and Left of Zero with the Rest of the Sample (Interval width $=\mathbf{0 . 0 0 5}$ )

\begin{tabular}{|c|c|c|c|c|c|c|c|c|c|c|}
\hline \multirow{2}{*}{$\begin{array}{c}\text { Variabl } \\
\text { es }\end{array}$} & \multicolumn{5}{|c|}{ Left of Zero Interval } & \multicolumn{5}{|c|}{ Right of Zero Interval } \\
\hline & $\begin{array}{c}\text { Cash } \\
\text { flow } \\
\text { from } \\
\text { operati } \\
\text { ons } \\
\end{array}$ & $\begin{array}{l}\text { Produc } \\
\text { tion } \\
\text { costs }\end{array}$ & $\begin{array}{c}\text { Discretio } \\
\text { nary } \\
\text { expenses }\end{array}$ & $\begin{array}{c}\text { Accrua } \\
\text { Is using } \\
\text { Jones }\end{array}$ & $\begin{array}{l}\text { Accrua } \\
\text { ls using } \\
\text { modifie } \\
\text { d Jones }\end{array}$ & $\begin{array}{c}\text { Cash } \\
\text { flow } \\
\text { from } \\
\text { operati } \\
\text { ons } \\
\end{array}$ & $\begin{array}{c}\text { Produc } \\
\text { tion } \\
\text { costs }\end{array}$ & $\begin{array}{c}\text { Discretio } \\
\text { nary } \\
\text { expenses }\end{array}$ & $\begin{array}{c}\text { Accrua } \\
\text { Is using } \\
\text { Jones }\end{array}$ & $\begin{array}{l}\text { Accrua } \\
\text { Is using } \\
\text { modifie } \\
\text { d Jones }\end{array}$ \\
\hline $\begin{array}{c}\text { Interce } \\
\text { pt }\end{array}$ & 0.0001 & $\begin{array}{c}- \\
0.0010\end{array}$ & 0.005 & $\begin{array}{c}- \\
0.0001\end{array}$ & $\begin{array}{c}- \\
0.0001\end{array}$ & 0.0001 & $\begin{array}{c}- \\
0.0009\end{array}$ & 0.0003 & $\begin{array}{c}- \\
0.0002\end{array}$ & $\begin{array}{c}- \\
0.0001\end{array}$ \\
\hline SIZE & $\begin{array}{c}0.0032 \\
*\end{array}$ & $\begin{array}{c}- \\
0.0040 \\
*\end{array}$ & 0.00007 & $\begin{array}{c}- \\
0.0226 \\
* * *\end{array}$ & $\begin{array}{c}- \\
0.230 * \\
* *\end{array}$ & $\begin{array}{c}0.0031 \\
*\end{array}$ & $\begin{array}{c}- \\
0.0040 \\
*\end{array}$ & $\begin{array}{c}- \\
0.00002 \\
* * *\end{array}$ & $\begin{array}{c}- \\
0.0226 \\
* * *\end{array}$ & $\begin{array}{c}- \\
0.0230 \\
* * *\end{array}$ \\
\hline MTB & 0.0004 & $\begin{array}{c}- \\
0.0011 \\
* *\end{array}$ & $\begin{array}{c}0.0014 * \\
* *\end{array}$ & $\begin{array}{c}- \\
0.0002\end{array}$ & $\begin{array}{c}- \\
0.0002\end{array}$ & 0.0004 & $\begin{array}{c}- \\
0.0011 \\
* * *\end{array}$ & $\begin{array}{c}0.0014 * \\
* *\end{array}$ & $0 . \overline{-}$ & $\begin{array}{c}- \\
0.0002\end{array}$ \\
\hline$N I$ & $\begin{array}{c}0.3757 \\
* * *\end{array}$ & $\begin{array}{c}- \\
0.1571 \\
* * *\end{array}$ & $\begin{array}{c}- \\
0.2646 * \\
* *\end{array}$ & $\begin{array}{c}0.3556 \\
* * *\end{array}$ & $\begin{array}{c}0.3568 \\
* * *\end{array}$ & $\begin{array}{c}0.3757 \\
* * *\end{array}$ & $\begin{array}{c}- \\
0.1572 \\
* * *\end{array}$ & $\begin{array}{c}- \\
0.2645^{*} \\
* *\end{array}$ & $\begin{array}{c}0.3556 \\
* * *\end{array}$ & $\begin{array}{c}0.3568 \\
* * *\end{array}$ \\
\hline $\begin{array}{c}\text { INTER } \\
\text { VAL }\end{array}$ & $\begin{array}{c}- \\
0.0083 \\
* *\end{array}$ & $\begin{array}{c}0.0322 \\
* * *\end{array}$ & $\begin{array}{c}- \\
0.0358 * \\
* *\end{array}$ & $\begin{array}{c}0.0084 \\
* *\end{array}$ & 0.0071 & $\begin{array}{c}- \\
0.0085 \\
*\end{array}$ & $\begin{array}{c}0.0268 \\
* * *\end{array}$ & $\begin{array}{c}- \\
0.0248 * \\
* *\end{array}$ & $\begin{array}{c}0.0096 \\
* * *\end{array}$ & $\begin{array}{c}0.0086 \\
*\end{array}$ \\
\hline
\end{tabular}

* This table reports the coefficients from the following regression:

$$
E M_{t}=\alpha+\alpha_{1}(S I Z E)_{t-1}+\alpha_{2}(M T B)_{t-1}+\alpha_{3}(N I)_{t}+\alpha_{4}(I N T E R V A L)_{t}+\sum_{j} \alpha_{5, j} \text { Year }_{j}+\varepsilon_{t}
$$

The above model is run separately for each model. EM stands for earnings management measures including abnormal cash flow from operations, abnormal production costs, abnormal discretionary expenses, abnormal accruals using the Jones and modified Jones methods which are residuals from the following regressions.

$$
\begin{aligned}
& \mathrm{CFO}_{t} / \mathrm{A}_{t-1}=\alpha_{0}+\alpha_{1}\left(1 / \mathrm{A}_{t-1}\right)+\alpha_{2}\left(\mathrm{~S}_{t} / \mathrm{A}_{t-1}\right)+\alpha_{3}\left(\Delta \mathrm{S}_{t} / \mathrm{A}_{t-1}\right)+\varepsilon_{t} \\
& \mathrm{DE}_{t} / \mathrm{A}_{t-1}=\alpha_{0}+\alpha_{1}\left(1 / \mathrm{A}_{t-1}\right)+\alpha_{2}\left(S_{t-1} / \mathrm{A}_{t-1}\right)+\varepsilon_{t} \\
& \mathrm{PC}_{t} / \mathrm{A}_{t-1}=\alpha_{0}+\alpha_{1}\left(1 / \mathrm{A}_{t-1}\right)+\alpha_{2}\left(S_{t} / \mathrm{A}_{t-1}\right)+\alpha_{3}\left(\Delta \mathrm{S}_{t} / \mathrm{A}_{t-1}\right)+\alpha_{4}\left(\Delta \mathrm{S}_{t-1} / \mathrm{A}_{t-1}\right)+\varepsilon_{t} \\
& \mathrm{AC}_{t} / \mathrm{A}_{t-1}=\alpha_{0}+\alpha_{1}\left(1 / \mathrm{A}_{t-1}\right)+\alpha_{2}\left(\Delta S_{t} / \mathrm{A}_{t-1}\right)+\alpha_{3}\left(\mathrm{PPE}_{t} / \mathrm{A}_{t-1}\right)+\varepsilon_{t} \\
& \mathrm{AC}_{t} / \mathrm{A}_{t-1}=\alpha_{0}+\alpha_{1}\left(1 / \mathrm{A}_{t-1}\right)+\alpha_{2}\left(\left[\Delta S_{t}-\Delta R E C_{t}\right] / \mathrm{A}_{t-1}\right)+\alpha_{3}\left(\mathrm{PPE}_{t} / \mathrm{A}_{t-1}\right)+\varepsilon_{t}
\end{aligned}
$$

$T$ statistics, reported in parentheses, are generated using Newey-West procedure to correct for autocorrelation and heteroskedasticity.

** Variables are as previously defined.

$*, * *, * * *$ represent that the coefficient is significant at $10 \%, 5 \%$, and $1 \%$, respectively. 
Table 3: Descriptive Statistics for Earnings Change

\begin{tabular}{|c|c|c|c|c|c|c|c|c|c|c|}
\hline \multirow{3}{*}{ Variable } & \multirow{2}{*}{\multicolumn{2}{|c|}{ Whole sample }} & \multicolumn{4}{|c|}{ Left of zero earnings change } & \multicolumn{4}{|c|}{ Right of zero earnings change } \\
\hline & & & \multicolumn{2}{|c|}{$\begin{array}{c}\text { Firms with small } \\
\text { decrease in } \\
\text { earnings }\end{array}$} & \multicolumn{2}{|c|}{ Rest of Sample } & \multicolumn{2}{|c|}{$\begin{array}{l}\text { Firms with small } \\
\text { increase in } \\
\text { earnings }\end{array}$} & \multicolumn{2}{|c|}{ Rest of Sample } \\
\hline & Mean & Median & Mean & Median & Mean & Median & Mean & Median & Mean & Median \\
\hline $\begin{array}{l}S(\$ \\
\text { million) }\end{array}$ & 7277.39 & 312.43 & 18600 & 564.28 & 6763.48 & 302.98 & 7343.57 & 568.17 & 7273.68 & 299.32 \\
\hline $\begin{array}{l}A(\$ \\
\text { million) }\end{array}$ & 7553.19 & 419.03 & 18500 & 1097.70 & 7053.68 & 398.28 & 8732.58 & 1261.82 & 7487.08 & 389.98 \\
\hline $\begin{array}{l}M V \$ \\
\text { (million) }\end{array}$ & 2923.45 & 365.09 & 3707.64 & 759.1 & 3040.07 & 376.09 & 3965.33 & 920.96 & 3018.95 & 371.5 \\
\hline MTB & 3.25 & 1.74 & 2.16 & 1.58 & 3.29 & 1.75 & 2.17 & 1.59 & 3.31 & 1.76 \\
\hline $\begin{array}{l}C F O(\$ \\
\text { million) }\end{array}$ & 635.02 & 30.70 & 1386.28 & 83.45 & 600.78 & 29.25 & 803.29 & 95.38 & 625.59 & 28.54 \\
\hline $\begin{array}{l}P C(\$ \\
\text { million })\end{array}$ & 4847.36 & 180.64 & 12300 & 363.78 & 4517.92 & 173.89 & 5552.67 & 339.79 & 4809.67 & 173.40 \\
\hline $\begin{array}{l}D E(\$ \\
\text { million) }\end{array}$ & 1421.62 & 65.52 & 3949.5 & 90.20 & 1307.82 & 64.85 & 1678.76 & 107.84 & 1407.51 & 64.28 \\
\hline $\begin{array}{l}A C(\$ \\
\text { million })\end{array}$ & -294.33 & -15.31 & -572.91 & -39.85 & -281.63 & -14.54 & -401.39 & -40.11 & -288.33 & -14.32 \\
\hline $\begin{array}{l}I(\$ \\
\text { million) }\end{array}$ & 340.55 & 10.72 & 813.37 & 31.17 & 319.01 & 9.93 & 401.90 & 39.11 & 337.11 & 9.47 \\
\hline$S / A$ & 1.13 & 0.91 & 0.99 & 0.77 & 1.13 & 0.92 & 0.94 & 0.74 & 1.14 & 0.92 \\
\hline CFO/A & 0.07 & 0.085 & 0.089 & 0.081 & 0.069 & 0.086 & 0.091 & 0.088 & 0.068 & 0.085 \\
\hline$P C / A$ & 0.80 & 0.57 & 0.76 & 0.54 & 0.80 & 0.57 & 0.71 & 0.50 & 0.80 & 0.57 \\
\hline$D E / A$ & 0.32 & 0.24 & 0.22 & 0.17 & 0.33 & 0.24 & 0.23 & 0.18 & 0.33 & 0.25 \\
\hline$A C / A$ & -0.07 & -0.054 & -0.046 & -0.041 & -0.070 & -0.055 & -0.045 & -0.044 & -0.071 & -0.551 \\
\hline
\end{tabular}

* This table presents the mean, median and standard deviation of the variables used in the models for small loss and small profit firms and the rest of sample as well as the whole sample.

** To lessen the effect of outliers, all the continuous variables are winsorized at 1 percent tails.

*** Variables are as previously defined. 
Table 4: Comparison of Intervals Right and Left of Zero Earnings Change with the Rest of the Sample (Interval width= 0.005)

\begin{tabular}{|c|c|c|c|c|c|c|c|c|c|c|}
\hline \multirow{2}{*}{$\begin{array}{c}\text { Variab } \\
\text { les }\end{array}$} & \multicolumn{5}{|c|}{ Left of zero change } & \multicolumn{5}{|c|}{ Right of zero change } \\
\hline & $\begin{array}{c}\text { Cash } \\
\text { flow } \\
\text { from } \\
\text { operat } \\
\text { ions }\end{array}$ & $\begin{array}{c}\text { Produ } \\
\text { ction } \\
\text { costs }\end{array}$ & $\begin{array}{c}\text { Discreti } \\
\text { onary } \\
\text { expense } \\
\text { s }\end{array}$ & $\begin{array}{c}\text { Accru } \\
\text { als } \\
\text { using } \\
\text { Jones }\end{array}$ & $\begin{array}{c}\text { Accru } \\
\text { als } \\
\text { using } \\
\text { modif } \\
\text { ied } \\
\text { Jones }\end{array}$ & $\begin{array}{l}\text { Cash } \\
\text { flow } \\
\text { from } \\
\text { operat } \\
\text { ions }\end{array}$ & $\begin{array}{c}\text { Produ } \\
\text { ction } \\
\text { costs }\end{array}$ & $\begin{array}{c}\text { Discreti } \\
\text { onary } \\
\text { expense } \\
\text { s }\end{array}$ & $\begin{array}{c}\text { Accru } \\
\text { als } \\
\text { using } \\
\text { Jones }\end{array}$ & $\begin{array}{c}\text { Accru } \\
\text { als } \\
\text { using } \\
\text { modif } \\
\text { ied } \\
\text { Jones }\end{array}$ \\
\hline $\begin{array}{c}\text { Interce } \\
\text { pt }\end{array}$ & $\begin{array}{c}0.0000 \\
3\end{array}$ & $\begin{array}{c}- \\
0.0015\end{array}$ & 0.0014 & $\begin{array}{c}- \\
0.000 \\
3\end{array}$ & $\begin{array}{c}0.000 \\
08\end{array}$ & $\begin{array}{c}- \\
0.0002\end{array}$ & $\begin{array}{c}- \\
0.0014\end{array}$ & 0.0013 & $\begin{array}{c}- \\
0.000 \\
3\end{array}$ & $\begin{array}{c}- \\
0.000 \\
9\end{array}$ \\
\hline SIZE & $\begin{array}{c}0.0032 \\
*\end{array}$ & $\begin{array}{c}- \\
0.0044 \\
*\end{array}$ & 0.0005 & $\begin{array}{c}- \\
0.022 \\
7 * * *\end{array}$ & $\begin{array}{c}- \\
0.023 \\
0 * * *\end{array}$ & $\begin{array}{c}0.0031 \\
*\end{array}$ & $\begin{array}{c}- \\
0.0043 \\
*\end{array}$ & 0.0005 & $\begin{array}{c}- \\
0.022 \\
7 * * *\end{array}$ & $\begin{array}{c}- \\
0.231 \\
* * *\end{array}$ \\
\hline MTB & 0.0004 & $\begin{array}{c}- \\
0.0011 \\
* *\end{array}$ & $\begin{array}{c}0.0014 * \\
* *\end{array}$ & $\begin{array}{c}- \\
0.000 \\
2\end{array}$ & $\begin{array}{c}- \\
0.000 \\
2\end{array}$ & 0.0004 & $\begin{array}{c}- \\
0.0011 \\
* * *\end{array}$ & $\begin{array}{c}0.0014 * \\
* *\end{array}$ & $\begin{array}{c}- \\
0.000 \\
2\end{array}$ & $\begin{array}{c}- \\
0.000 \\
2\end{array}$ \\
\hline$N I$ & $\begin{array}{c}0.3757 \\
* * *\end{array}$ & $\begin{array}{c}- \\
0.1574 \\
* * *\end{array}$ & $\begin{array}{c}- \\
0.2641 * \\
* *\end{array}$ & $\begin{array}{l}0.355 \\
5 * * *\end{array}$ & $\begin{array}{c}- \\
0.356 \\
8 * * *\end{array}$ & $\begin{array}{c}0.3756 \\
* * *\end{array}$ & $\begin{array}{c}- \\
0.1574 \\
* * *\end{array}$ & $\begin{array}{c}- \\
0.2641 * \\
* *\end{array}$ & $\begin{array}{l}0.355 \\
5 * * *\end{array}$ & $\begin{array}{l}0.356 \\
8 * * *\end{array}$ \\
\hline $\begin{array}{c}\text { INTER } \\
\text { VAL }\end{array}$ & $\begin{array}{c}- \\
0.0009\end{array}$ & $\begin{array}{c}0.0270 \\
* * *\end{array}$ & $\begin{array}{c}- \\
0.0387^{*} \\
* *\end{array}$ & $\begin{array}{l}0.007 \\
4 * * *\end{array}$ & $\begin{array}{c}- \\
0.000 \\
9\end{array}$ & 0.0035 & $\begin{array}{c}0.0179 \\
* * *\end{array}$ & $\begin{array}{c}- \\
0.0274 * \\
* *\end{array}$ & $\begin{array}{l}0.006 \\
1 * * *\end{array}$ & $\begin{array}{c}0.006 \\
3 *\end{array}$ \\
\hline
\end{tabular}

* This table reports the coefficients from the following regression:

$$
E M_{t}=\alpha+\alpha_{1}(S I Z E)_{t-1}+\alpha_{2}(M T B)_{t-1}+\alpha_{3}(N I)_{t}+\alpha_{4}(I N T E R V A L)_{t}+\sum_{j} \alpha_{5, j} Y_{e a r}+\varepsilon_{t}
$$

The above model is run separately for each model and EM stands for earnings management measures including abnormal cash flow from operations, abnormal production costs, abnormal discretionary expenses, abnormal accruals using the Jones and modified Jones methods. $T$ statistics, reported in parentheses, are generated using Newey-West procedure to correct for autocorrelation and heteroskedasticity.

** Variables are as previously defined.

$*, * *, * * *$ represent that the coefficient is significant at $10 \%, 5 \%$, and $1 \%$, respectively. 
Table 5: Comparison of Suspect Firms with the Rest of the Sample (0.01 width)

\begin{tabular}{|c|c|c|c|c|c|c|c|c|c|c|}
\hline \multirow{2}{*}{$\begin{array}{c}\text { Variab } \\
\text { les }\end{array}$} & \multicolumn{5}{|c|}{ Left of Zero Interval } & \multicolumn{4}{|c|}{ Right of Zero } & \multirow[b]{2}{*}{$\begin{array}{c}\text { Accrua } \\
\text { ls } \\
\text { using } \\
\text { modifi } \\
\text { ed } \\
\text { Jones }\end{array}$} \\
\hline & $\begin{array}{c}\text { Cash } \\
\text { flow } \\
\text { from } \\
\text { operati } \\
\text { ons }\end{array}$ & $\begin{array}{c}\text { Produc } \\
\text { tion } \\
\text { costs }\end{array}$ & \begin{tabular}{|l} 
Discretio \\
nary \\
expenses
\end{tabular} & $\begin{array}{l}\text { Accrua } \\
\text { ls } \\
\text { using } \\
\text { Jones }\end{array}$ & $\begin{array}{c}\text { Accrua } \\
\text { ls } \\
\text { using } \\
\text { modifi } \\
\text { ed } \\
\text { Jones }\end{array}$ & $\begin{array}{c}\text { Cash } \\
\text { flow } \\
\text { from } \\
\text { operati } \\
\text { ons }\end{array}$ & $\begin{array}{l}\text { Produc } \\
\text { tion } \\
\text { costs }\end{array}$ & $\begin{array}{c}\text { Discretio } \\
\text { nary } \\
\text { expenses }\end{array}$ & $\begin{array}{l}\text { Accrua } \\
\text { ls } \\
\text { using } \\
\text { Jones }\end{array}$ & \\
\hline $\begin{array}{c}\text { Interce } \\
\text { pt }\end{array}$ & 0.0002 & $\begin{array}{c}- \\
0.001 \\
2 \\
\end{array}$ & 0.0007 & -0.0002 & -0.0001 & 0.0004 & -0.0016 & 0.0011 & -0.0004 & -0.0004 \\
\hline SIZE & $\begin{array}{c}0.0032 \\
*\end{array}$ & $\begin{array}{c}- \\
0.004 \\
1 * \\
\end{array}$ & 0.00007 & $\begin{array}{c}- \\
0.0226 \\
* * *\end{array}$ & $\begin{array}{c}- \\
0.0230 \\
* * *\end{array}$ & $\begin{array}{c}0.0031 \\
*\end{array}$ & $\begin{array}{c}- \\
0.0039 \\
*\end{array}$ & -0.0001 & $\begin{array}{c}- \\
0.0225 \\
* * *\end{array}$ & $\begin{array}{c}- \\
0.0229 \\
* * *\end{array}$ \\
\hline MTB & 0.0004 & $\begin{array}{c}- \\
0.001 \\
1 * * *\end{array}$ & $0.0014 * * *$ & -0.0002 & -0.0002 & 0.0004 & $\begin{array}{c}- \\
0.0011 \\
* * *\end{array}$ & $\begin{array}{c}0.0014^{* *} \\
*\end{array}$ & -0.0002 & -0.0002 \\
\hline$N I$ & $\begin{array}{c}0.3757 \\
* * *\end{array}$ & $\begin{array}{c}- \\
0.157 \\
0 * * *\end{array}$ & $-0.2646 * * *$ & $\begin{array}{c}0.3556 \\
* * *\end{array}$ & $\begin{array}{c}0.3568 \\
* * *\end{array}$ & $\begin{array}{c}0.3757 \\
* * *\end{array}$ & $\begin{array}{c}- \\
0.1572 \\
* * *\end{array}$ & $\begin{array}{c}- \\
0.2644 * * \\
*\end{array}$ & $\begin{array}{c}0.3555 \\
* * *\end{array}$ & $\begin{array}{c}0.3567 \\
* * *\end{array}$ \\
\hline $\begin{array}{c}\text { INTER } \\
\text { VAL }\end{array}$ & $\begin{array}{c}- \\
0.0096 \\
* * *\end{array}$ & $\begin{array}{l}0.028 \\
9 * * *\end{array}$ & $-0.0311 * * *$ & $\begin{array}{c}0.0073 \\
* *\end{array}$ & $\begin{array}{c}0.0057 \\
*\end{array}$ & $\begin{array}{c}- \\
0.0094 \\
* * *\end{array}$ & $\begin{array}{c}0.0327 \\
* * *\end{array}$ & $\begin{array}{c}- \\
0.0340 * * \\
*\end{array}$ & $\begin{array}{c}0.0116 \\
* * *\end{array}$ & $\begin{array}{c}0.0109 \\
* * *\end{array}$ \\
\hline
\end{tabular}

* This table reports the coefficients from the following regression:

$$
E M_{t}=\alpha+\alpha_{1}(S I Z E)_{t-1}+\alpha_{2}(M T B)_{t-1}+\alpha_{3}(N I)_{t}+\alpha_{4}(I N T E R V A L)_{t}+\sum_{j} \alpha_{5, j} \text { Year }_{j}+\varepsilon_{t}
$$

The above model is run separately for each model. EM stands for earnings management measures including abnormal cash flow from operations, abnormal production costs, abnormal discretionary expenses, abnormal accruals using the Jones and modified Jones methods. $T$ statistics, reported in parentheses, are generated using the Newey-West procedure to correct for autocorrelation and heteroskedasticity.

** Variables are as previously defined.

$*, * *, * * *$ represent that the coefficient is significant at $10 \%, 5 \%$, and $1 \%$ respectively. 